\title{
A reflection on the philosophy of economics in Kinh tế Việt Nam: Thăng trầm và đột phá
}

\author{
Ho Manh Tung \\ Ritsumeikan Asia Pacific University
}

January 15,2021

Published in 2009, Kinh tế Việt Nam: Thăng trầm và đột phá (hereinafter, "the book") provides a comprehensive account of historical developments of Vietnam's economy from 1945 to 2008 [1]. The authors skillfully guide us through the intricacies of the rise and fall of the Vietnamese economy through the bloody two wars with the French (19451954) and the American (1955-1975), then the stale period after 1975, the turmoil and soaring time after 1986 (the Doi Moi period).

The book is full of statistics, dates, tables, charts, yet, to look beyond those numbers, the readers can quickly see the attempt to wrestle with the bigger philosophical questions about Vietnamese cultural identity and the kind of political economy that bring the best out of such cultural identity [2,3].

As a reader and an early career researcher, it appears that while writing a book of that scale, those philosophical concerns must naturally arise. Perhaps, given the vicissitudes of the nation's situation, it is a natural instinct to rise above the numbers, the dates, the tables, and the charts, to see a bigger narrative that plays out. It is also an instinct to reflect on Vietnamese perspectives of the tumultuous period of human history: the battles between imperialism versus national independence, capitalism versus communism.

Throughout the book, the readers are asked to reflect with the authors on philosophical questions such as what is the origin of wealth? What is the role of cultural identity in generating wealth? What are the principles that guide human behaviors in the stock market? What are the respective roles of the market and the government? How to 
strike a balance between economic independence and interdependence? How to conceptualize a unique branch of Vietnamese economic studies?

Let's look at an example at the center of the classical debate of economic theories: the relationship between the government and the market. The authors build their case for the respective role of each entity on two principles: the freedom to make transactions and efficiency of information sharing through the pricing mechanism. For the market and the government to work well together, they must eliminate obstacles to these basic principles. However, the authors also stress the importance of each individual having an effective mechanism in receiving information and acting on it; otherwise, information sharing efficiency will be wasted [1: 500]. This emphasis on building a mechanism to receive information and act on it correctly is a reflection of the mindsponge model, which is developed after seven years $[4,5]$.

At the end of the book, where the authors express all the hope for a breakthrough in economic development in Vietnam, each component's role in the triad of the government-market-individual is once again emphasized. For a well-functioning economy, the market must be allowed to operate its self-correcting mechanism. Yet, the government must be strong in that they need to maintain relative independence of economic and financial policies, energy, and food security for the nation. The authors state the root of the government's strength is not how much resources they can command but the solidarity of all government levels and the people.

More importantly, a competitive economy is constituted by competitive cells, as healthy cells can generate energy for their own survival. Finally, the readers are left with a thought on the independence of an economic development model, which must be based on pragmatic concerns and creative thinking [6].

If I have something to add, it will be about our current grave environmental concern. The ongoing climate breakdown tells us that any future reliable economic model cannot ignore to address this serious problem. Once again, the huge philosophical question on this matter has started being answered by the book's co-author [7-8]. And to me, the answer has so far been remarkable. 


\section{References}

1. Chính, P. M., \& Hoàng, V. Q. (2009). Kinh tế Việt Nam: Thăng trầm và đột phá. Nxb Chính trị Quốc gia, Hà Nội.

2. Vuong, Q.-H., Ho, M.-T., Nguyen, H.-K. T., et al. (2020). On how religions could accidentally incite lies and violence: folktales as a cultural transmitter. Palgrave Communications, 6(1), 82. doi:10.1057/s41599-020-0442-3

3. Vuong, Q.-H., Bui, Q.-K., La, V.-P., et al. (2019). Cultural evolution in Vietnam's early 20th century: A Bayesian networks analysis of Hanoi Franco-Chinese house designs. Social Sciences \& Humanities Open, 1(1), 100001. doi:https://doi.org/10.1016/j.ssaho.2019.100001

4. Vuong, Q. H. (2016). Global mindset as the integration of emerging socio-cultural values through mindsponge processes: A transition economy perspective. In J. Kuada (Ed.), Global Mindsets: Exploration and Perspectives (pp. 109-126). London: Routledge.

5. Vuong, Q. H., \& Napier, N. K. (2015). Acculturation and global mindsponge: an emerging market perspective. International Journal of Intercultural Relations, 49, 354-367.

6. Vuong, Q. H., \& Napier, N. K. (2014). Making creativity: the value of multiple filters in the innovation process. International Journal of Transitions and Innovation Systems, 3(4), 294-327.

7. Vuong, Q. H. (2020). From children's literature to sustainability science, and young scientists for a more sustainable Earth. Journal of Sustainability Education, 24(3), $1-12$.

8. Vuong, Q. H. (2021). The semiconducting principle of monetary and environmental values exchange. Economics and Business Letters, 10(3), in press. 